\title{
Managing Information Communication Technology and Effectiveness of Electricity Distribution Companies: A Re-Strategizing and Evolving Paradigms
}

\section{Eromafuru Edward Godbless ${ }^{1}$ OMOYE Ezie Israel ${ }^{2}$}

${ }^{\prime}$ Department of Business Administration, Delta State University, Abraka, Nigeria. Email:eeromafuru@yahoo.com

${ }^{2}$ Department of Business Administration and Management, Delta State University, Abraka, Nigeria. Email: ezieisrael@gmail.com

\begin{abstract}
Preponderance of literature on the effects of information communication technology addressed ICT functionality and usage majorly, leaving a lacuna in strategic alignment and management of ICT systems and processes. The study investigates the impact of Information Communication Technology Management (ICTM) on organizational effectiveness of Electricity Distribution Companies. Hypotheses were formulated to guide the study which relied on the survey research design. The population consisting of 937 was taken from the staff of the major electricity distribution companies in Nigerian namely: Port-Harcourt and Benin Electricity Distribution companies and subsidiaries; a sample of 280 was selected. Questionnaire was structured and administered through online survey. Consistency of instruments was confirmed at Cronbach Alpha value of 0.93 and Confirmatory Factor Analysis used to assess strength of the good fit of variables that predict the variables. Results affirmed significant relationship between ICTM's constructs of facility availability, integration, polices, and effectiveness of Nigerian Electricity Distribution Companies.
\end{abstract}

Keywords: Information communication technology, Management, Effectiveness, ICT integration, ICT management policy, Electricity distribution companies.

Citation | Eromafuru Edward Godbless; OMOYE Ezie Israel (2022). Managing Information Communication Technology and Effectiveness of Electricity Distribution Companies: A ReStrategizing and Evolving Paradigms. Asian Journal of Social Sciences and Management Studies, 9(1): 1-10.

\section{History:}

Received: 15 December 2021

Revised: 18 January 2022

Accepted: 31 January 2022

Published: 11 February 2022

Licensed: This work is licensed under a Creative Commons

Attribution 3.0 License (c)

Publisher: Asian Online Journal Publishing Group
Funding: This study received no specific financial support

Authors' Contributions: Both authors contributed to the conception and design of the study.

Competing Interests: The authors declare that they have no conflict of interests.

Transparency: The authors confirm that the manuscript is an honest, Transparency: The authors confirm that the manuscript is an honest,
accurate, and transparent account of the study; that no vital features of the study have been omitted; and that any discrepancies from the study as planned have been explained.

Ethical: This study followed all ethical practices during writing.

\section{Contents}

1. Introduction

2. Literature Review

3. Methodology

4. Results.

5. Discussion.

6. Implications for Theory, Research Value, and Future Research .

7. Conclusion

References 


\section{Contribution of this paper to the literature}

The study contributes to the existing literature on ICT and its management through integration of key ICTM practices vis-à-vis effectiveness of EDC. The study is presumably the first to investigate how integrated constructs of ICTM can be adapted to the operational and strategic needs of EDC in Nigeria and Diasporas.

\section{Introduction}

The growing interest and researches in information technology notwithstanding, there is paucity of evidence to support management of the ICT infrastructures for organisational and operational efficiency of the EDC in Nigeria (Basri, Alandejani, \& Almadani, 2015; Mousa, 2013). This is even as prolific and erudite writers have stressed the need to ensure proper management of the infrastructures to enhance their capacity to deliver and in keeping pace with the emerging information revolution (Cuevas-Vargas, Estrada, \& Larios-Gómez, 2016; Hashem, 2015; Kyle \& Muhammad, 2015; Williams, 2011). In recent times, ICT has been viewed as a green area of growth partly due to its novel ideas and dynamic and demanding nature of the business environment (Allen \& Morton, 2004; Faisal \& Kisman, 2020). Unarguably, ICT infrastructure has been thought of as improving efficiency, achieving cost effectiveness, and enhancing quality products and service delivery to customers and clients (Allen \& Morton, 2004). In the same vein, ICT has been considered a strategic tool for marketing, outsourcing and contacting stakeholders as well as presenting ICT services to distinguished potential services users (UNDP, 2001; Werthner \& Klein, 2005). ICT integration has made many corporate organizations resilient amidst strong opposition in the organizational environment (Chege, Wang, \& Suntu, 2020). Evidently, most corporate organization thrived in spite of the ravaging pandemic of COVID-19 and lockdown enforced by government and other regulating agencies (Hyunjin, Taejung, \& Jongwon, 2020). Most ICT-oriented organizations have taken advantage of the opportunity necessitated by the ravaging syndrome to advance their legitimate cause and corporate existence. In the recent times, ICT has been trending in almost all areas of organization sphere covering product decision and distribution spectrum. Against the above backdrop, it has become self-evident that ICT has become a major vehicle through which products information reach their target costumers even before the physical product gets to them (Stawnicza, 2014).Many organizations, ranging from governmental, private to public are now begin to embrace the importance and usefulness of ICT with little or no attention given to ICTM. ICT in recent times has been a major link between the organization and its stakeholders such as the staff, customers, buyers and suppliers (Leavitt, 2004).With the advent of ICT, organizations have developed capabilities to provide efficient services to their customers and prospective ones (Bird, 2010), Basically, for many companies, e-mail is the principal means of communication between employees, suppliers and customers and over the decades, a good number of communication tools have evolved thus facilitating use of live-chat systems, online meeting using zoom, and videoconferencing (Patru \& Petrache, 2011). With the evolving communication devices such as Voice over internet protocol (VOIP) and smart-phones, interactions between employees and employers have been made easier (Hyunjin et al., 2020). Further to this, some organization install ICT for the purpose of advertisement and for capturing and tracking sales and online payments through portals (Patru \& Petrache, 2011). Battistella and De Toni (2011) advocated that an organizational absorptive capacity is a prerequisite to installing an appropriate technological infrastructure and stimulating innovations. Consequently, the role of top management in designing effective structures and technological infrastructures to stimulate unhindered information flow cannot be outstretched (Ermelinda, Gorica, \& Ahmetaj, 2011; Kamal, 2011; Naqshbandi \& Kamel, 2017). ICTM has made possible adaptation of latent innovations and devices thus triggering opportunities for integrating new processes, models and methods with new ICT solutions. It therefore becomes germane to gauge the strategic impact of ICTM on organisational effectiveness of the NGBs amid evolving information and knowledge technology.

\section{Literature Review}

\subsection{Conceptualization of ICT Management}

A corporate organization is supposedly established for profitability while maintaining uninterrupted service delivery in the environment it situates. It calls to reason that the obviously growing trend of activities surrounding the use of ICT calls for its effective management in all facets of the organization (Birchall \& Giambona, 2008; Chirani \& Tirgar, 2013). However, some organization could outsource ICT services rather than integrating and installing any (Hanafizadeh \& Zareravasan, 2020). The advent of ICT has given rise to installations of Automatic Teller Machines (ATM), Point of Sales (POS) and Prepaid Meter Machines (PMM) mostly used by Electricity Power Distribution Company in Nigeria (Hashem, 2015; Patru \& Petrache, 2011). Battistella and De Toni (2011). Despite their potential strategic relevance, oftentimes satisfactions or dissatisfactions could result from how the ICT facilities are used of calling for the efficient management of the process (Cuevas-Vargas et al., 2016; Tezci, 2009). In the absence of effective management platform, decision making becomes problematic as records are not always readily available and any strategic misstep can be fatal and can abruptly obliterate an organization that has taken years to build (Hashem, 2015). Consequently, vital issues such as customer's needs and demand, suppliers and stakeholders' information may turn out to be elusive. Leavitt (2004) saw information communication technology as output consisting of organizational image, product and services to be distributed to the frontend users. Most organizations are starved of information that can improve and enhance their performance, thus justifying case for ICT Management to improve their operations (Aristovnik, 2012); thus aligning with the observation by scholars that no meaningful improvement can be made if ICT facilities are not adequately and appropriately managed (Brown, 2016). Qosasi et al. (2019) revealed that ICTs have been used by organization in a wide range of business applications with significant strategic undertones. ICTs' relevance can also be inferred from the fact they provide opportunities and help in dramatic reductions in the cost of obtaining, processing, and transmitting information which are increasingly changing the business landscape in the contemporary society (Heath, Maghrabi, \& Carr, 2015). The vast changes in ICTs make technology undisputedly the backbone of commerce (Brynjolfsson, Rock, \& Syverson, 2019). Technology underpins the operations of individual companies, ties together far-flung supply chains, and increasingly links businesses to customers they serve (Nakata, Zhu, \& Kraimer, 2008). With 
information communication technologies underpinning the way businesses operate, it is not surprising that business spending on these ICTs continues to grow with its attendant returns. The US Department of Commerce's Bureau of Economic Analysis recorded 1965 figures of American companies' expenditure on information technology at less than 5\%. By the end of the 1990s, this figure rose to near $50 \%$ of expenditure. In the heat of spiral down-turn in expenditure on information technology in the early 20oos, businesses around the world continue to spend well over $\$ 2$ trillion” per annum on ICT’s (Heath et al., 2015). Prastacos, Söderquist, Spanos, and Van Wassenhove (2002) also see that technology changes are occurring at increasing rates. The change, coupled with the wide application of these technological developments, has recorded a breakthrough among management scholars and ICT practitioners. In many industries nowadays, the existence and effectiveness of any organizations depend largely on the exhaustive application of information communication technology (ICT) and the way it is managed (Ermelinda et al., 2011). Organizations are intensely seeking to apply information communication technology to support existing business, and to create competitive advantages. Over the years, ICT has been thought of significantly changing corporate behavior and organization structure, which should increase productivity (Brynjolfsson et al., 2019). The internet resource is extending to other platforms such as commerce, entertainment, communication, and industry. Over the globe, monthly internet traffic in 2010 is two-third higher than one year ago (Naqshbandi \& Kamel, 2017). Information on cost is supplied by accounting section and the capacities and technology to be available in the future depend greatly on financial investments, both planned and recently undertaken. Demands hinge not only on the marketing strategy of the firm, but on the competition and the economic climate (McClain \& Thomas, 2003).

\subsection{Hypotheses Development}

Research works on ICT while presumably sound and strategically compelling, may have ignored the managerial impacts of ICT deployment and usage for competitive enhancement of an enterprise. Nigel, Kraemer, and Gurbaxani (2004) undertook a study on "Information technology and Organizational Performance: An Integrative Model of IT Business Value". The study involved exploratory review of literature on the association between information technology and organizational performance. Study found that IT was valuable, but the extent and dimensions are dependent upon internal and external factors including complementary organizational resources of the firm and its trading partners as well as the competitive and macro environment. Fernandez and Borias (2008) investigated the impact of ICT on organizational performance in a Brewing in Dublin, Ireland, using a sample of 300 respondents from five departments of the Brewing namely Brewing, Engineering, Marketing, Distribution and Safety Departments. The study employed research survey design and found that ICT had a positive and significant impact on organizational performance in the Brewing he studied. In a related study by Jalagat and Al-Habsi (2017) the study found significant positive relationship between IT's use of variables of internet applications, mobile and devices, data management system and college performance in the measures of financial performance, accountability, quality service and operational efficiency. Studies have also buttressed strong correlation between ICT utilization and improving performance of employees in Local Government Administrations in South Africa. In another study, Day, Paquet, Scott, and Hambley (2012) deployed Exploratory Structural Equation Modeling to assess the moderating effect of organisational ICT support in the interface of perceived information and communication technology demands on employees and outcomes with the results showing partial moderating effects. A study was conducted by Sagir (2013) on impact of organizations as Information Communication Processors on the Effectiveness of a Brewery industry in Lagos using a sample of 260 respondents, interviewed through structured and undisguised questionnaire Study affirmed positive relations between ICT and effectiveness of organizations. Although the study made appreciative impacts on ICT usage, it made limited impacts on management of ICT in the organizations. In their empirical study to investigate the ICTbased innovations on organisational performance, Yunis, El-Kassar, and Tarhini (2017) found corporate entrepreneurship mediating the relationships. Study was however limited by research scope in use of instrument and sampling procedure. The corollary of this study was effort by Nyarko \& Kozari to assess the use of ICTs among agricultural extension workers and implications on service delivery extension. With a sample of 153 field extension workers, structured questionnaire was adapted to glean information from sample respondents. Statistical packages including IBM and SPSS version-22 were instrumental bases for analysis. Finding had it that agricultural extension officers use ICT for personal communication beyond extension activities. Aligning with the above, the hypotheses to be tested are:

H1. There is no relationship between ICT integration and organizational effectiveness.

H2. There is no relationship between ICT availability and effectiveness of organization.

H3. There is no relationship between ICT management polices organizational effectiveness.

The model that explains the above relationships is shown in the Figure 1:

The below model illustrates how ICTM's constructs of integration, infrastructures and management policies relate to measures of organisational effectiveness of productivity, commitment, competitiveness, cost reduction, profitability and organisational image. of Electricity Distribution Company of Nigeria (EDCN).

\section{Methodology}

This research work adopted a descriptive survey design in exploring the opinions of the respondents on relationship between ICTM and organizational effectiveness of EDC. The population of 937 from which a sample size of 280 was randomly selected, consisted of all employees of the EDC in South-South Nigeria namely: The Port-Harcourt Electric Power Distribution Company (EPDC) Plc in Rivers state; and the Benin Electricity Power Distribution Company (EPDC) plc in Edo state. The Port-Harcourt and Benin Grids have subsidiaries in Balyesa and Delta states respectively. Electronics e-mail survey through structured questionnaire was used to elicit responses from sampled employees. The mailed Questionnaire was organized in two sections - A and B, in which A dealt with demography of the respondents and $\widetilde{B}$ for obtaining information pertaining to the subject focus of the research. A five-point Likert scale was designed to elicit responses ranging from strongly agree (SA - 5), agree (A $4)$, neutral ( $\mathrm{N}-1)$, disagree (D - 3), and strongly agree (SD - 2). 


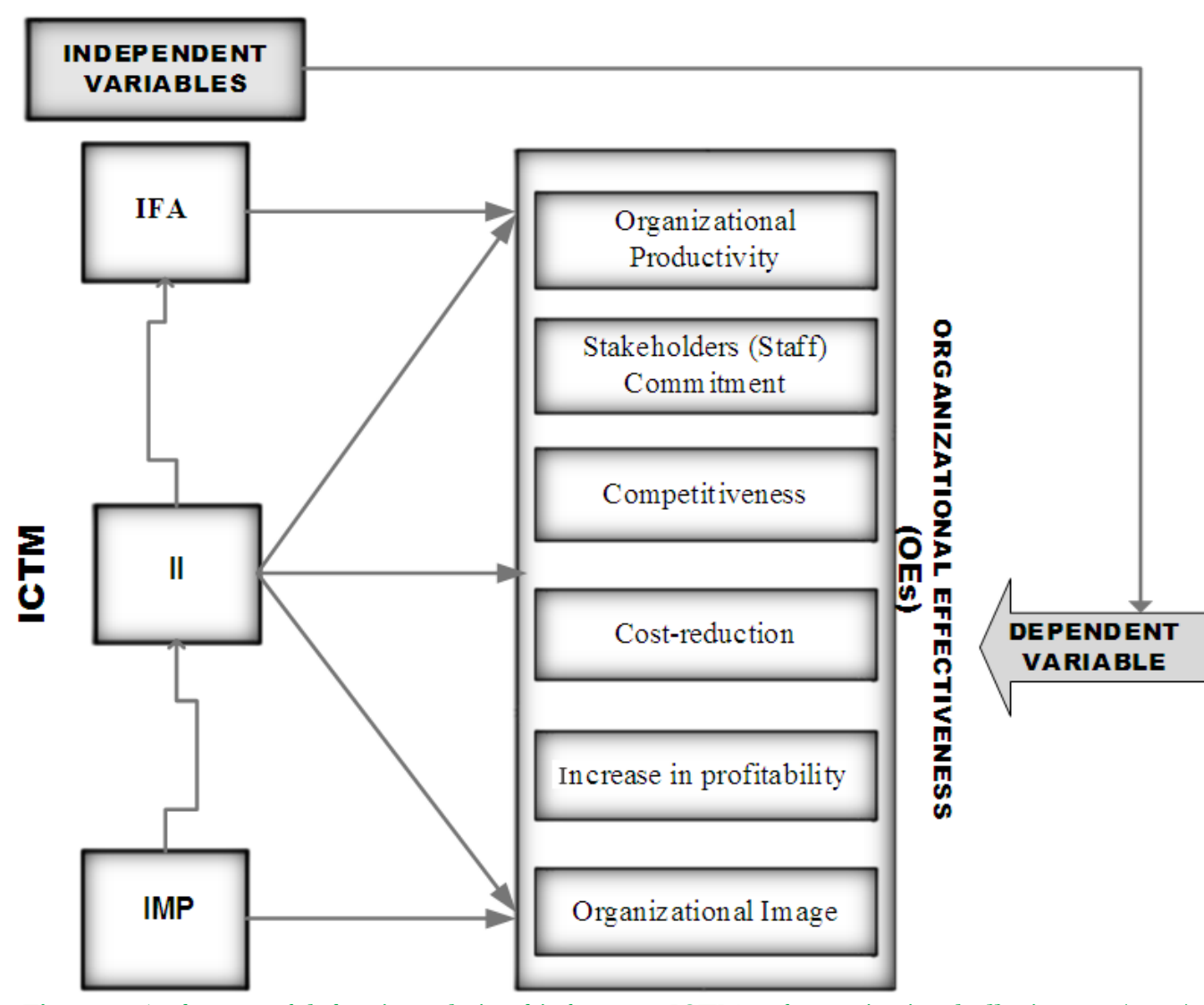

Instrument reliability Appendix B was confirmed at Cronbach's alpha $(\alpha=0.93)$ and content validity (Straub, Boudreau, \& Gefen, 2004) was deployed to measure the appropriateness of the research instruments. Confirmatory Factor analysis was used to test for the good-fit of the variable for the analysis Appendix C. The CFA carried out, complements the investigation result and erodes every doubt about the validity of the questionnaire used for the analysis. Descriptive statistics of the Mean, and standard deviation were used for the analysis whereas Pearson Product Moment Correlations (PPMC) alongside multiple regression engaged to test the hypotheses by means of the Statistical Packages for Social Sciences, version 26.1, at $\mathrm{p}<0.05$ level of significance. Also Microsoft Visio 2016 for Management Model Development software was used for the Conceptual framework.

Model specifications are:

$$
\begin{aligned}
& \text { OEs }=\partial_{0}+\partial_{1}, \text { IFA }+E_{1} \\
& \text { OEs }=\beta_{0}+\beta_{1}, \text { II }+E_{2} \\
& \text { OEs }=\delta_{0}+\delta_{1}, \text { IMP }+E_{3}
\end{aligned}
$$

Where $\chi_{0}, \beta_{0}, \delta_{0}$, are the constant terms while $ð_{1}, \beta_{1}, \delta_{1}$, are the coefficients

Whereas $\mathrm{E}_{1} \ldots \mathrm{E}_{6}$ are the Error terms.

OEs = Organizational Effectiveness.

IFA $=$ ICT Facility Availability.

II $\quad=$ ICT Integration.

IMP = ICT Management Policy.

\section{Results}

\subsection{Descriptive Analysis of ICTM Constructs}

Table 1 depicts the descriptive analysis of the mean value of ICT facilities availability among the electricity distribution company in the south-south Nigeria. All the mean shown in the table are above the bench mark of 2.5 except, IFA_2 (2.0564 \pm 0.867$)$, this is because the electricity distribution company has not fully embraced the optimal use of POS and PMM machines for operations, therefore the responses were below acceptable limit. The highest mean value IFA_3 (3.664 \pm 0.679$)$ above 2.5 acceptable limits was obtained as a result of the high use of

\begin{tabular}{|c|c|c|c|c|}
\hline Variable & ICT Facility Availability & Mean & $\begin{array}{c}\text { Std. } \\
\text { Deviation }\end{array}$ & Remark \\
\hline IFA_1 & We have multimedia such as projector for management board meetings & 3.179 & 0.659 & Agree \\
\hline IFA_2 & $\begin{array}{l}\text { My organization has introduced the use of P.O.S Machine, Prepay Meter } \\
\text { Machine (PMM) and customers use them }\end{array}$ & 2.036 & 0.867 & Disagree \\
\hline IFA_3 & $\begin{array}{l}\text { Our organization has internet connectivity and websites for our online } \\
\text { services such as e-mail addresses }\end{array}$ & 3.664 & 0.679 & Agree \\
\hline IFA_4 & $\begin{array}{l}\text { We have ICT Department fully equipped for functional ICT and } \\
\text { telecommunication services (telephone calls) }\end{array}$ & 3.236 & 0.458 & Agree \\
\hline IFA_5 & We have Wi-Fi and Mi-fi and intercom facilities & 2.625 & 0.976 & Agree \\
\hline
\end{tabular}
internet connectivity and websites for online services such as e-mail addresses.

Table 1. Descriptive analysis of the mean value of ICT facility availability 
A grasp at Table 2 reveals the mean statistics of value of ICT integration. The mean responses are all above bench mark of 2.5 level of acceptance. The highest mean obtainable was identified with II_5 (3.671 \pm 0.580$)$ with the affirmation that memo and information letters are communicated to stakeholders easily through the use of ICT.

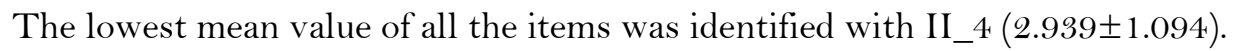

Table 2. Descriptive analysis of the mean value of ICT integration.

\begin{tabular}{|c|c|c|c|c|}
\hline Variable & ICT Integration & Mean & $\begin{array}{c}\text { Std. } \\
\text { Deviation }\end{array}$ & Remark \\
\hline II_1 & $\begin{array}{l}\text { Our staff has been trained on the use of ICT facilities and thus enhance } \\
\text { workflow }\end{array}$ & 3.750 & 0.517 & Agree \\
\hline II_2 & $\begin{array}{l}\text { Our organization has migrated from manual and traditional to automated } \\
\text { payment mechanism }\end{array}$ & 3.754 & 0.568 & Agree \\
\hline II_3 & We use collaborative work through staff engagement in use of ICT & 3.157 & 0.840 & Agree \\
\hline II_4 & $\begin{array}{l}\text { Our organization share information and communication resource easily } \\
\text { between staff }\end{array}$ & 2.939 & 1.094 & Agree \\
\hline II_5 & $\begin{array}{l}\text { Memo, and information letters are communicated stakeholders easily } \\
\text { through the use of ICT }\end{array}$ & 3.671 & 0.580 & Agree \\
\hline
\end{tabular}

The descriptive statistics in Table 3 shows the mean value of ICT Management Policy, with each dimension assuming the value above the bench mark of 2.5. This means that the electricity distribution company has good knowledge of ICT policy and it is being implemented satisfactorily for the benefit of the stakeholders. However, item IMP $4(3.154 \pm 0.843)$ show that effort need to be made to periodically review and modified ICT polices to reflect challenges in ICT business environment.

Table 3. Descriptive analysis of the mean value of ICT management policy.

\begin{tabular}{|c|c|c|c|c|}
\hline Variable & ICT Management Policy & Mean & $\begin{array}{c}\text { Std. } \\
\text { Deviation } \\
\end{array}$ & Remark \\
\hline IMP_1 & Our organization has an ICT guide to decision making or action & 3.668 & 0.472 & Agree \\
\hline IMP_2 & We have a laid-down course of action with the organization & 3.593 & 0.492 & Agree \\
\hline IMP_3 & $\begin{array}{l}\text { Our organization laid-down the limits within which ICT decisions are } \\
\text { made and operated }\end{array}$ & 3.104 & 0.877 & Agree \\
\hline $\mathrm{IMP}_{4} 4$ & $\begin{array}{l}\text { We periodically reviewed and modified ICT policies to reflect challenges } \\
\text { in ICT business environment }\end{array}$ & 3.154 & 0.843 & Agree \\
\hline IMP_5 & Our ICT policies is to an extent is to adopt ICT to reduce managerial cost & 3.443 & 0.546 & Agree \\
\hline
\end{tabular}

The descriptive analysis of the mean value for organizational effectiveness is reflected in Table 4. On the measures of organisational effectiveness, agreement was reached among the respondents that ICT installation has increased productivity and profitability margin; and stakeholders' commitment to the organization, and has benefited the organization better than traditional and manual operation. The mean value for the items being above 2.5 bench mark limit is within the acceptance range.

Table 4. Descriptive analysis of the mean value of organisational effectiveness.

\begin{tabular}{|c|c|c|c|c|}
\hline Variable & Organisational Effectiveness & Mean & $\begin{array}{c}\text { Std. } \\
\text { Deviation }\end{array}$ & Remark \\
\hline OEs_1 & ICT installation has increased our productivity and profit margin & 3.755 & 0.432 & Agree \\
\hline OEs_2 & ICT Management has increased stakeholders' commitment to the organization & 3.429 & 0.674 & Agree \\
\hline OEs_3 & $\begin{array}{l}\text { ICT management has benefited our organization better than traditional and } \\
\text { manual operating }\end{array}$ & 3.825 & 0.381 & Agree \\
\hline OEs_4 & $\begin{array}{l}\text { ICT management in our organization has helped to keep sales information } \\
\text { intact }\end{array}$ & 3.557 & 0.539 & Agree \\
\hline OEs_5 & We get information easily from our stakeholders & 3.904 & 0.371 & Agree \\
\hline
\end{tabular}

\begin{tabular}{|c|c|c|c|c|c|c|c|c|c|c|}
\hline Variable & \multicolumn{3}{|c|}{ OEs } & \multicolumn{3}{|c|}{1} & \multicolumn{3}{|c|}{2} & 3 \\
\hline OEs & \multicolumn{3}{|c|}{1.000} & & & & & & & \\
\hline IFA & \multicolumn{3}{|c|}{-0.023} & \multicolumn{3}{|c|}{1.000} & & & & \\
\hline II & \multicolumn{3}{|c|}{0.258} & \multicolumn{3}{|c|}{-0.271} & \multicolumn{3}{|c|}{1.000} & \\
\hline IMP & \multicolumn{3}{|c|}{0.218} & \multicolumn{3}{|c|}{$-0.605^{*}$} & \multicolumn{3}{|c|}{0.290} & 1.000 \\
\hline $\mathbf{R}$ & \multicolumn{3}{|c|}{ R Square } & \multicolumn{3}{|c|}{ Adjusted R Square } & \multicolumn{4}{|c|}{ Std. Error of the Estimate } \\
\hline $0.348^{\mathrm{a}}$ & \multicolumn{3}{|c|}{0.121} & \multicolumn{3}{|c|}{0.105} & \multicolumn{4}{|c|}{0.357} \\
\hline \multicolumn{11}{|l|}{ ANOVA $^{a}$} \\
\hline Model & \multicolumn{3}{|c|}{ Sum of Squares } & \multicolumn{3}{|c|}{ Df } & \multicolumn{2}{|c|}{ Mean Square } & $\mathbf{F}$ & Sig. \\
\hline Regression & \multicolumn{3}{|c|}{4.822} & \multicolumn{3}{|c|}{5} & \multicolumn{2}{|c|}{0.964} & 7.561 & $0.000^{\mathrm{b}}$ \\
\hline Residual & \multicolumn{3}{|c|}{34.949} & \multicolumn{3}{|c|}{274} & \multicolumn{2}{|c|}{0.128} & & \\
\hline Total & \multicolumn{3}{|c|}{39.771} & \multicolumn{3}{|c|}{279} & & & & \\
\hline \multicolumn{11}{|c|}{ Coefficients $^{\mathrm{a}}$} \\
\hline & \multicolumn{2}{|c|}{$\begin{array}{l}\text { Unstandardized } \\
\text { Coefficients }\end{array}$} & & $\begin{array}{l}\text { ardized } \\
\text { icients }\end{array}$ & $\mathbf{T}$ & Sig. & $\begin{array}{r}95.0 \% \mathrm{C} \\
\text { Interv }\end{array}$ & $\begin{array}{l}\text { fidence } \\
\text { for B }\end{array}$ & $\begin{array}{r}\text { Collin } \\
\text { Stati }\end{array}$ & $\begin{array}{l}\text { earity } \\
\text { stics }\end{array}$ \\
\hline Model & B & $\begin{array}{l}\text { Std. } \\
\text { Error }\end{array}$ & & eta & & & $\begin{array}{l}\text { Lower } \\
\text { Bound }\end{array}$ & $\begin{array}{l}\text { Upper } \\
\text { Bound }\end{array}$ & Toleranc & VIF \\
\hline (Constant) & 1.230 & 0.494 & & & 2.488 & 0.013 & 0.257 & 2.202 & & \\
\hline IFA & 0.152 & 0.085 & & 149 & 1.788 & 0.075 & -0.015 & 0.320 & 0.460 & 2.174 \\
\hline II & 0.242 & 0.064 & & 228 & 3.808 & 0.000 & 0.117 & 0.368 & 0.891 & 1.122 \\
\hline IMP & 0.263 & 0.102 & & 235 & 2.587 & 0.010 & 0.063 & 0.463 & 0.389 & 2.569 \\
\hline
\end{tabular}

Note: Dependent Variable = OEs (Organizational Effectiveness).

Independent Variable = IFA (ICT Facility Availability), II (ICT Integration) and IMP (ICT Management Policy).

Source: Researcher Computation, using SPSS Version 26). 


\subsection{Hypotheses testing}

Table 5a displays the result of multiple logistic regressions (LR) performed in determining the level of prediction of IFA, II and IMP to OEs, IFA $(\beta=1.788, \mathrm{P}=0.075)$; II $(\beta=3.808, \mathrm{P}=0.000)$; and IMP $(\beta=2.587, \mathrm{P}$ $=0.010)$. Results strengthen the evidence that ICT integration and ICT management policy contributed significantly to organizational effectiveness (OEs). The '*' in the correlation matrix shows high correlation $(\mathrm{r}=-$ 0.605) which suggests further analysis of LR. The logistic regression column, 'a' depicts the R-value of the predictors (independent variables, IFA, II and IMP) showing 0.348 contribution to the dependent variable OEs. The ' $\mathrm{b}$ ' reflects the $\mathrm{F}$-ratio $(\mathrm{r}=7.561)$ which is significant at $\mathrm{p}=0.000<0.05$, thus affirming strength of relationship. The column, IFA $(t=1.788, p=0.075)$, II $(t=3.808, p=0.000)$ and $\operatorname{IMP}(t=2.587, p=0.010)$ support the standardized coefficient, IFA (0.149), II (0.228) and IMP (0.235). In the confidential interval, IMP shows high lower and upper bound $(0.063$ - 0.463) evident that II and IMP contributed more significantly than IFA (ICT in predicting Organizational Effectiveness (OEs) at $\mathrm{p}<0.05$ level of significance. Furthermore, with the Variance Inflation Factor (VIF $=2.174,1.122$ and 2.569) being below the level of diagnosing which is 10, it implies low tolerance of co linearity in the regression analysis. The model plot with factor correlation categorically explained the above table clearly.

\section{Model 1}

$H_{1}$. There is relationship between ICT Availability and organizational effectiveness.

The covariance estimated standard $(0.575)$ and calculated $(\mathrm{p}=0.001<0.05)$ makes the hypothesis statistically significant leading to the rejection of the null hypothesis. The ICT Availability and organizational effectiveness have relationship (see Appendix C).

\section{Model 2}

$H_{2}$ There is relationship between ICT Integration and effectiveness of organization.

This the covariance estimated standard (0.413) and calculated p- value (0.001) less than 0.05 level of significance imply that the hypothesis is statistically significant. Consequent upon the above result, the ICT Integration and organizational effectiveness have relationship (see Appendix C).

\section{Model 3}

$H_{s}$ There is relationship between ICT Management Polices organizational effectiveness.

With covariance output of estimated standard (0.908) calculated p- value (0.001) less than 0.05 level of significances strengthens the evidence that the hypothesis is statistically significant and implies rejection of the null hypothesis (see appendix). The ICT Management Policy and organizational effectiveness have relationship. Off the three factors predicted organizational effectiveness, ICTM Policy has higher value of correlation than the other two factors.

\subsection{Factor Correlation Analysis of ICTM Variables}

The factor analysis and model pilot showing how ICTM constructs correlate with measures of organisational effectiveness is aptly depicted in Table $5 \mathrm{~b} \&$ Figure 2:

\begin{tabular}{|c|c|c|c|c|c|c|}
\hline & \multirow{2}{*}{ Estimate } & \multirow{2}{*}{ Std. Error } & \multirow{2}{*}{ z-value } & \multirow{2}{*}{$\mathbf{p}$} & \multicolumn{2}{|c|}{ 95\% Confidence Interva } \\
\hline & & & & & Lower & Upper \\
\hline \multirow{3}{*}{$\begin{array}{l}\mathrm{IFA} \leftrightarrow \mathrm{II} \\
\mathrm{IFA} \leftrightarrow \mathrm{IMP} \\
\mathrm{II} \leftrightarrow \mathrm{IMP}\end{array}$} & $0.575 \mathrm{a}$ & 0.063 & 9.070 & $<0.001$ & 0.451 & 0.699 \\
\hline & $0.413 \mathrm{~b}$ & 0.052 & 7.955 & $<0.001$ & 0.515 & 0.311 \\
\hline & $0.908 \mathrm{c}$ & 0.046 & 19.688 & $<0.001$ & 0.998 & 0.817 \\
\hline
\end{tabular}

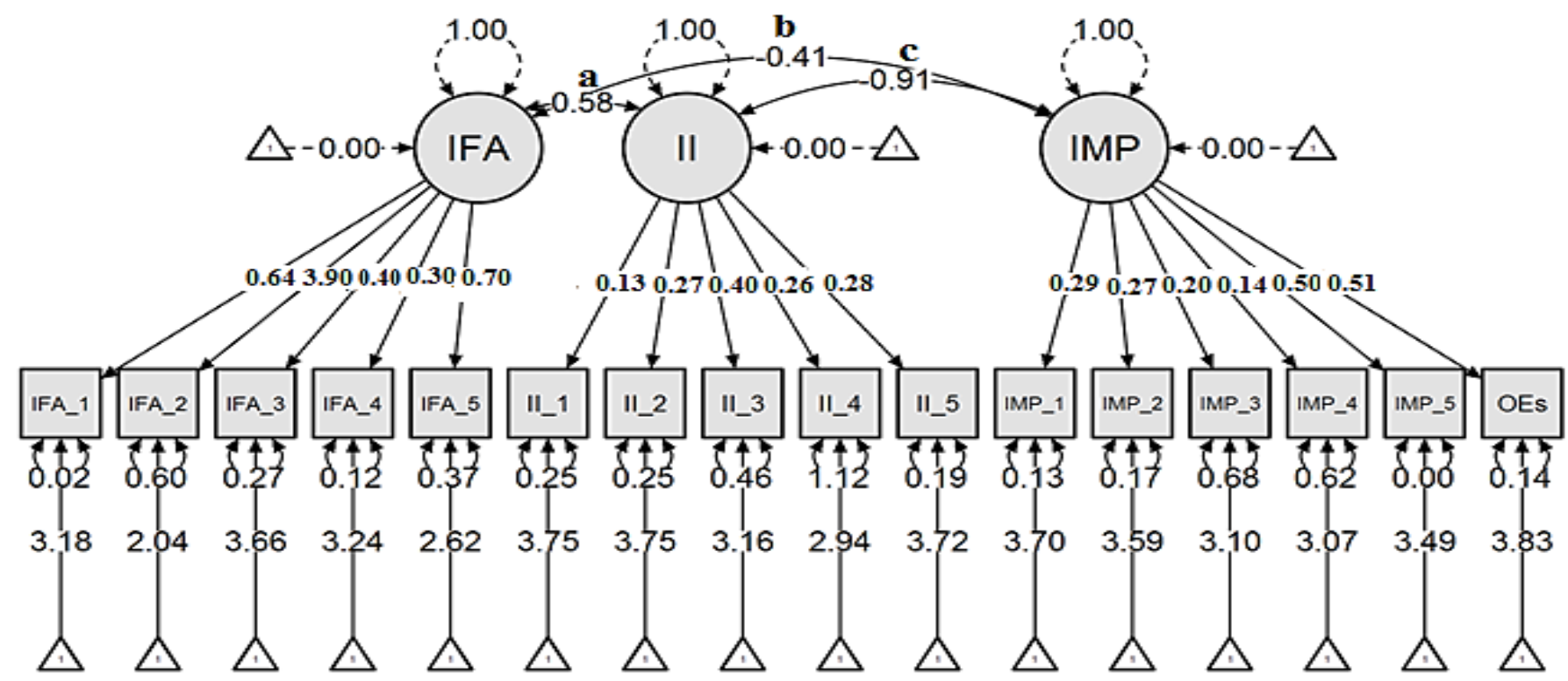

Figure 2. Factor analysis of the correlation of information communication management variables as it impacts on organizational effectiveness of electricity distribution companies in the South-South Nigeria. 
The above model plot is an output of the Confirmatory Factor Analysis (see appendix) designed to examine the nature of the relationships between the observed measures or the predictors, where IFA and IMP predicting OEs = 0.58 ' II and IMP predicting OEs $=0.91$; and IFA and IMP predicting OEs $=0.41$. The posited measurement model for the 20-items with five Likert scale is as presented in the model plot (see Figure 2 ). The conventional model plot notations are depicted by circles and indicators by rectangles or squares. Factor loadings can be found on the large unidirectional arrows, and are clearly outlined in the tables of factor covariance (see Appendix C) where all are positive and significant. Consequently, in the model plot (Figure 2), all the factor loadings are significant at $(0.001<0.05)$ level of significance. All the variances and residuals have positive values which shows that the predictor (IFA, II and IMP) are positive and significantly determines the dependent variable (OEs) thus IMP which is ICT Management Policy has higher relationship value (0.91) than the other two, IFA (0.58) and II ( $0.41)$.

\section{Discussion}

From the model 1, finding has shown evidence of significant relationship between ICT Facility Availability (IFA) and organizational effectiveness (OEs) of electricity distribution companies in Nigeria. Evidently organisational effectiveness will to a large extent be affected by integration and deployment of ICT facilities. It is no doubt that a number of organizations are craving for new technology to remain at the competitive edge. In addition, the model specification has revealed effective usage of ICT resources at management board meeting and the introduction of innovative ICT devices have helped to facilitate the distribution of electricity companies; notwithstanding, the finding has revealed that the use of these machines are in low key. The second finding has shown that ICT integration significantly impact on organizational effectiveness in south-south Nigeria. This was exhibited in table 4.9 under summary of multiple regression analysis for hypothesis 2 . Results align with the findings of Ssewanyana and Busler (2007) that investigated the extent of incorporating and usage of ICT on one hundred and ten firms with respect to their contributions. The above evidence correlates with the current study in such areas as ICT integration and utilization. Heeks (2002) also advocated that ICT integration is far-reaching than firms sourcing ICT contract from external firms. This, study has confirmed would not give organizations an upper grip on the ICT system. Findings from the second hypothesis conform to the work of Hyunjin et al. (2020). The finding from the analysis of third hypothesis affirms that ICT management polices significantly influence organizational effectiveness of Electricity Distribution Companies in Nigeria. The result accords with (Calder, 2011). The effect of size of the ICT Management on the Organizational effectiveness is even more visible with the variables of the ICT Management Policy as could be seen in Table $5(\mathrm{~b})$. This is aspect is the central focus of this research.

\section{Implications for Theory, Research Value, and Future Research}

The piece of research work revolves around existing theories on ICTM through construction and validation of model relating typologies of ICTM to effectiveness of Electricity distribution companies in Nigeria. While it could be averred that research endeavors in this area have addressed the use, benefits, impacts and trends of ICT, literature on the management of the ICT is still scanty. It becomes imperative that strategies and processes for managing ICT infrastructures be developed in order to optimize ICT effectiveness. It is within this context that this research found its originality as it is the first of its kind in the pool of extant literature that underscored the place of management processes in the use of ICT resources. Implicated in the above is the need to review ICT management policy periodically to meet the increasing dynamics in the ICT environment. It is also instructive to assert that proper management of ICT device availability and integration will bear positively on the organizational effectiveness. Moreover, the study will form a vital platform for other researchers and pointed grey areas to research into related areas such as customers' opinion and satisfaction with ICT's device and its consumption in the south-south, Nigeria. Future research may also conduct a comparative analysis of ICTM deployment, use and integration across countries.

\section{Conclusion}

Electricity Distribution Companies in the South-South Nigeria are majorly two: the Benin Electric Distribution Company controlling the Edo and Delta region, and the Port-Harcourt Electricity Distribution Company controlling Rivers, Bayelsa, Akwa-Ibom and Cross-Rivers states. The study stressed the need for the regional power grids to adopt the Information Communication Technology in their effort to ensure swift and stable distribution of electricity in the region. To be fully integrated and for effectiveness, the distributing companies must brace-up actions to imbibe rudiments of sound management practices. Even as at now, quite a handful of companies have deployed prepay meter machine (PMM) and Point of Sales (POS) machine to assist the stakeholders and investors in designated areas. The ICT Facilities Availability is yet to cover all the South-South Nigeria. Consequently, the study has foreclosed the strategic bearing of ICTM constructs of ICT availability, ICT integration and ICT management policy on the organizational effectiveness of the Electricity Distribution Companies.

\section{References}

Allen, T., \& Morton, M. (2004). Information technology and the corporation of the 1990s. New York: Oxford University Press.

Aristovnik, A. (2012). The impact of ICT on educational performance and its efficiency in selected EU and OECD countries: A nonparametric analysis. Turkish Online Journal of Educational Psychology, 11(3), 144-152.Available at: https://doi.org/10.2139/ssrn.2187482.

Basri, W., Alandejani, J. A., \& Almadani, F. M. (2015). ICT adoption impacts on students' academic performance: Evidence from Saudi universities. Educational Research International, 2018, 1-9.Available at: https://doi.org/10.1 155/2018/1240197.

Battistella, C., \& De Toni, A. F. (2011). A methodology of technological foresight: A proposal and field study. Technological Forecasting and Social Change, 78(6), 1029-1048.Available at: https://doi.org/10.1016/j.techfore.2011.01.006.

Birchall, D. W., \& Giambona, G. (2008). The impact of ICT on the work patterns of managers and their organisations. EuroMed Journal of Business, 3(3), 244-262.Available at: https://doi.org/10.1108/14502190810906428. 
Bird, A. (2010). Social knowing: The social sense of'scientific knowledge'. Philosophical Perspectives, 24, 23-56.Available at: https://doi.org/10.1111/j.1520-8583.2010.00184.x.

Brown, N. (2016). ICT in the primary curriculum in the UK. Paper presented at the Proceedings of the International Conference for KSSEE's 30th Anniversary: Future tasks and prospects of elementary education in the era of artificial intelligence and information Society, Korean Society for the study of Elementary Education.

Brynjolfsson, E., Rock, D., \& Syverson, C. (2019). Artificial intelligence and the modern productivity paradox: A clash of expectations and statistics (pp. 23-60): University of Chicago Press.

Calder, P. C. (2011). Information and communication technology (ICT) policy; Significances, challenges, issues and future research framework. Australian Journal of Basic and Applied Sciences, 5(12), 963-969.

Chege, S. M., Wang, D., \& Suntu, S. L. (2020). Impact of information technology innovation on firm performance in Kenya. Information Technology for Development, 26(2), 316-345.Available at: https://doi.org/10.1080/02681 102.2019.1573717.

Chirani, \& Tirgar. (2013). Information technology's role in organization's performance. Arabian Journal of Business and Management, 3(1), 1622.

Cuevas-Vargas, H., Estrada, S., \& Larios-Gómez, E. (2016). The effects of ICTs as innovation facilitators for a greater business performance. Evidence from Mexico. Procedia Computer Science, 91, 47-56.Available at: https://doi.org/10.1016/j.procs.2016.07.040.

Day, A., Paquet, S., Scott, N., \& Hambley, L. (2012). Perceived information and communication technology (ICT) demands on employee outcomes: The moderating effect of organizational ICT support. Journal of Occupational Health Psychology, 17(4), 473-491.Available at: https://doi.org/10.1037/a0029837.

Ermelinda, K., Gorica, K., \& Ahmetaj, L. (2011). Managing it infrastructure for information society development. The Albanian Case. Romanian Economic and Business Review, 6(2), 122-131.

Faisal, P., \& Kisman, Z. (2020). Information and communication technology utilization effectiveness in distance education systems. International Journal of Engineering and Business Management, 12, 1847979020911872.Available at: https://doi.org/10.1177/1847979020911872.

Fernandez, F. G., \& Borias, A. C. C. (2008). The relationship between ICTies and new organizational forms: Reference of the manufacturing industry in the area of Caraboba, Venezuela. Journal of Technology Management and Innovation, 3(4), 152 - 165. Available at: https://doi.org/10.4067/s0718-27242008000200012.

Hanafizadeh, P., \& Zareravasan, A. (2020). A systematic literature review on IT outsourcing decision and future research directions. Journal of Global Information Management (JGIM), 28(2), 160-201.Available at: https://doi.org/10.4018/jgim.2020040108.

Hashem, E. A. (2015). The impact of ICT investment on human development. International Journal of Management Sciences, 5(1), 11 1-124.

Heath, D., Maghrabi, R., \& Carr, N. (2015). Implications of information and communication technologies (ICT) for school-home communication. Journal of Information Technology Education: Research, 14, 363-396.Available at: https://doi.org/10.28945/2285.

Heeks, R. (2002). Failure, success and improvisation of information systems projects in developing countries. Development Informatics Working Paper, 11, 1-23.Available at: https://doi.org/10.2139/ssrn.3477762.

Hyunjin, C., Taejung, P., \& Jongwon, S. (2020). What should be considered when developing ICT-integrated classroom models for developing country? Sustainability Journal, 12(29), 1-19.

Jalagat, R., \& Al-Habsi, N. (2017). Evaluating the impacts of IT usage on organizational performance. European Academic Research, 5(9), 5111 5164 .

Kamal, M. M. (2011). The case of EAI facilitating knowledge management integration in local government domain. International Journal of Information Management, 31(3), 294-300.Available at: https://doi.org/10.1016/j.ijinfomgt.2011.02.002.

Kyle, D. P., \& Muhammad, H. (2015). Enhancing communication between management and employees at a storage organization in the freight industry. Problems and Perspectives in Management, 13(2), 193-201.Available at: https://doi.org/10.1080/15416518.2016.1222787.

Leavitt, H. J. (2004). Applied organizational change in industry: Structural, technological and humanistic approaches. Handbook of Organizations.In J.G March (Ed.). Chicago, IL: Rand McNally (Reviewed).

McClain, L., \& Thomas, J. (2003). On the interface between operations and human resources management. Manufacturing \& Service Operations Management, 5(3), 179-202.Available at: https://doi.org/10.1287/msom.5.3.179.16032.

Mousa, M. (2013). Aliterature on information communication technology and management in organizations. SIU Journal of Management, 3(2), 1-33.

Nakata, C., Zhu, Z., \& Kraimer, M. L. (2008). The complex contribution of information technology capability to business performance. Journal of Managerial Issues, 20(4), 485-506.

Naqshbandi, M. M., \& Kamel, Y. (2017). Intervening role of realized absorptive capacity in organizational culture-open innovation relationship: Evidence from an emerging market. Journal of General Management, 42(3), 5-20.Available at: https://doi.org/10.1177/0306307016687984.

Nigel, M., Kraemer, K., \& Gurbaxani, V. (2004). Information technology and organizational performance: An integrative model of IT business value. MIS Quarterly, 28(2), 283-322.

Patru, C., \& Petrache, A. (2011). Information technology management. Journal of Knowledge Management, Economics and Information Technology, 1(2), 1-6.

Prastacos, G., Söderquist, K., Spanos, Y., \& Van Wassenhove, L. (2002). An integrated framework for managing change in the new competitive landscape. European Management Journal, 20(1), 55-71.Available at: https://doi.org/10.1016/s0263-2373(01)00114-1.

Qosasi, A., Maulina, E., Purnomo, M., Muftiadi, A., Permana, E., \& Febrian, F. (2019). The impact of information and communication technology capability on the competitive advantage of small businesses. Industrial Engineering, 1O(1), 167-177.Available at: https://doi.org/10.14716/ijtech.v10i1.2332.

Sagir, A. M. (2013). An accurate computation of block hybrid method for solving tiff ordinary differential equations. International Journal of Mathematical and Computational Sciences, 7(4), 1307-6802.

Ssewanyana, J., \& Busler, M. (2007). Adoption and usage of ICT in developing countries: Case of Ugandan firms. International Journal of Education and Development Using ICT, 3(3), 49-59.

Stawnicza, O. (2014). Information and communication technologies-creating oneness in globally distributed IT project teams. Procedia Technology, 16, 1057-1064.Available at: https://doi.org/10.1016/j.protcy.2014.10.060.

Straub, D., Boudreau, M. C., \& Gefen, D. (2004). Validation guidelines for IS positivist research. Communications of the Association for Information Systems, 13(1), 24.Available at: https://aisel.aisnet.org/cais/vol 13/iss 1/24.

Tezci, E. (2009). Teachers' effect on ICT use in education: The Turkey sample. Procedia-Social and Behavioral Sciences, 1(1), 1285-1294.

UNDP. (2001). HDR making new technologies work for human development, human development report office (HDRO), United Nations Development Programme (UNDP). Retrieved from: https://ideas.repec.org/b/hdr/report/hdr2001.htmlDecember.

Werthner, H., \& Klein, S. (2005). ICT-enabled innovation in travel and tourism: Innovation and product development in Tourism. International Journal of Technology, 12(7), 11-21.

Williams, E. (2011). Environmental effects of information and communications technologies. Nature, 479(73), 354-358.

Yunis, M., El-Kassar, A.-N., \& Tarhini, A. (2017). Impact of ICT-based innovations on organizational performance: The role of corporate entrepreneurship. Journal of Enterprise Information Management, 30(1), 122-141.Available at: https://doi.org/10.1 108/jeim-01-20160040. 
Appendix A. Presents confirmatory factor analysis (CFA) with model fit

\begin{tabular}{|c|c|c|c|}
\hline \multicolumn{4}{|l|}{ Chi-square test } \\
\hline Model & $\mathrm{X}^{2}$ & Df & $\mathbf{p}$ \\
\hline Baseline model & 3656.800 & 120 & \\
\hline Factor model & 2448.554 & 101 & $<0.001$ \\
\hline
\end{tabular}

Table 2. Parameter estimates.

\begin{tabular}{|c|c|c|c|c|c|c|c|c|}
\hline \multicolumn{9}{|c|}{ Factor loadings } \\
\hline Factor & Indicator & Symbol & Estimate & Std. Error & z-value & p & Lower & Upper \\
\hline \multirow{5}{*}{ IFA } & IFA_1 & д11 & 0.644 & 0.030 & 21.400 & $<0.001$ & 0.585 & 0.703 \\
\hline & IFA_2 & д12 & 0.388 & 0.050 & 7.738 & $<0.001$ & 0.289 & 0.486 \\
\hline & IFA_3 & ð13 & -0.434 & 0.037 & -11.730 & $<0.001$ & -0.506 & -0.361 \\
\hline & IFA_4 & д14 & 0.300 & 0.025 & 12.091 & $<0.001$ & 0.251 & 0.349 \\
\hline & IFA_5 & д15 & 0.761 & 0.050 & 15.178 & $<0.001$ & 0.662 & 0.859 \\
\hline \multirow{5}{*}{ II } & II_1 & $\beta 21$ & -0.131 & 0.032 & -4.047 & $<0.001$ & -0.195 & -0.068 \\
\hline & II_2 & $\beta 22$ & -0.274 & 0.035 & -7.893 & $<0.001$ & -0.342 & -0.206 \\
\hline & II_3 & $\beta 23$ & -0.495 & 0.051 & -9.755 & $<0.001$ & -0.594 & -0.395 \\
\hline & II_4 & $\beta 24$ & 0.264 & 0.069 & 3.849 & $<0.001$ & 0.130 & 0.399 \\
\hline & II_5 & $\beta 25$ & -0.277 & 0.031 & -8.835 & $<0.001$ & -0.338 & -0.215 \\
\hline \multirow{5}{*}{ IMP } & IMP_1 & $\delta 31$ & 0.286 & 0.025 & 11.231 & $<0.001$ & 0.236 & 0.336 \\
\hline & IMP_2 & $\delta 32$ & -0.273 & 0.028 & -9.832 & $<0.001$ & -0.327 & -0.219 \\
\hline & IMP_3 & $\delta 33$ & -0.295 & 0.051 & -5.743 & $<0.001$ & -0.395 & -0.194 \\
\hline & IMP_4 & $\delta 34$ & -0.143 & 0.048 & -2.997 & 0.003 & -0.236 & -0.049 \\
\hline & IMP_5 & $\delta 35$ & 0.546 & 0.026 & 20.652 & $<0.001$ & 0.494 & 0.598 \\
\hline OEs & OEs & 36 & -0.011 & 0.023 & -0.495 & 0.621 & -0.055 & 0.033 \\
\hline
\end{tabular}

Appendix B. Cronbach-alpha reliability test.

[DataSet 1] C: $\backslash$ Users $\backslash$ Isytech-Zinox $\backslash$ Desktop $\backslash$ Reliability Calculation. Sav

Table 1. Warnings.

Each of the following component variables has zero variance and is removed from the scale: Q.18, Q.24.

The determinant of the covariance matrix is zero or approximately zero. Statistics based on its inverse matrix cannot be computed and they are displayed as system missing values.

Table 2. Scale: All variables.

\begin{tabular}{|c|c|c|c|}
\hline \multicolumn{4}{|c|}{ Case Processing Summary } \\
\hline & & $\mathbf{N}$ & $\%$ \\
\hline \multirow{3}{*}{ Cases } & Valid & 2 & 100.0 \\
\hline & Excludeda & $\mathrm{O}$ & 0.0 \\
\hline & Total & 2 & 100.0 \\
\hline
\end{tabular}

Note: a. Listwise deletion based on all variables in the procedure.

Table 3. Reliability statistics.

\begin{tabular}{c|c|c}
\hline Cronbach's Alpha & Cronbach's Alpha Based on Standardized Items & N of Items \\
\hline 0.932 & 0.964 & 28 \\
\hline
\end{tabular}

Table 4. Item statistics

\begin{tabular}{|c|c|c|c|}
\hline & Mean & Std. Deviation & $\mathbf{N}$ \\
\hline Q.1 & 35.0000 & 7.07107 & 30 \\
\hline Q.2 & 27.5000 & 7.77817 & 30 \\
\hline Q.3 & 27.5000 & 6.36396 & 30 \\
\hline Q.4 & 28.5000 & 3.53553 & 30 \\
\hline Q.5 & 24.5000 & 6.36396 & 30 \\
\hline Q.6 & 21.5000 & 13.43503 & 30 \\
\hline Q.7 & 15.0000 & 19.79899 & 30 \\
\hline Q.8 & 19.0000 & 24.04163 & 30 \\
\hline Q.9 & 25.5000 & 19.09188 & 30 \\
\hline Q.10 & 21.5000 & 7.77817 & 30 \\
\hline Q.11 & 21.0000 & 9.89949 & 30 \\
\hline Q.12 & 27.0000 & 15.55635 & 30 \\
\hline Q.13 & 30.5000 & 3.53553 & 30 \\
\hline Q.14 & 31.5000 & 2.12132 & 30 \\
\hline Q.15 & 28.5000 & 9.19239 & 30 \\
\hline Q.16 & 25.5000 & 3.53553 & 30 \\
\hline Q.17 & 32.0000 & 8.48528 & 30 \\
\hline Q.19 & 30.0000 & 1.41421 & 30 \\
\hline Q.20 & 28.0000 & 1.41421 & 30 \\
\hline Q.21 & 15.5000 & 19.09188 & 30 \\
\hline Q.22 & 20.0000 & 8.48528 & 30 \\
\hline Q.23 & 27.0000 & 2.82843 & 30 \\
\hline
\end{tabular}




\begin{tabular}{l|l|l|l}
\hline Q.25 & 28.5000 & 0.70711 & 30 \\
\hline Q.26 & 22.0000 & 11.31371 & 30 \\
\hline Q.27 & 32.0000 & 8.48528 & 30 \\
\hline Q.28 & 34.5000 & 7.77817 & 30 \\
\hline Q.29 & 30.5000 & 12.02082 & 30 \\
\hline Q.30 & 28.5000 & 10.60660 & 30 \\
\hline
\end{tabular}

Table 4. Summary item statistics.

\begin{tabular}{c|c|c|c|c|c|c|c}
\hline & Mean & Minimum & Maximum & Range & Maximum / Minimum & Variance & N of Items \\
\hline Item Means & 26.357 & 15.000 & 35.000 & 20.000 & 2.333 & 27.571 & 28 \\
\hline
\end{tabular}

Appendix C. Presents confirmatory factor analysis (CFA) with the removal of unrelated item *

Table 1. Factor variances.

\begin{tabular}{l|c|c|c|c|c|c}
\hline \multicolumn{9}{c|}{} & \multicolumn{2}{c}{ 95\% Confidence Interval } \\
\hline Factor & Estimate & Std. Error & z-value & p & Lower & Upper \\
\hline IFA & 1.000 & 0.000 & 9.071 & $<0.001$ & 1.000 & 1.000 \\
\hline II & 1.000 & 0.000 & -7.954 & $<0.001$ & 1.000 & 1.000 \\
\hline IMP & 1.000 & 0.000 & -19.701 & $<0.001$ & 1.000 & 1.000 \\
\hline
\end{tabular}

Table 2. Factor covariances.

\begin{tabular}{l|c|c|c|c|c|c}
\hline \multicolumn{9}{|c}{} & \multicolumn{2}{c}{ 95\% Confidence Interval } \\
\hline Factor & Estimate & Std. Error & z-value & P & Lower & Upper \\
\hline IFA $\leftrightarrow$ II & 0.575 & 0.063 & 9.071 & $<0.001$ & 0.451 & 0.699 \\
\cline { 2 - 7 } IFA $\leftrightarrow$ IMP & -0.413 & 0.052 & -7.954 & $<0.001$ & -0.515 & -0.311 \\
\cline { 2 - 7 } II $\leftrightarrow$ IMP & -0.908 & 0.046 & -19.701 & $<0.001$ & -0.998 & -0.818 \\
\hline
\end{tabular}

Table 3. Residual variances

\begin{tabular}{|c|c|c|c|c|c|c|}
\hline \multirow[b]{2}{*}{ Indicator } & \multirow[b]{2}{*}{ Estimate } & \multirow[b]{2}{*}{ Std. Error } & \multirow[b]{2}{*}{ z-value } & \multirow[b]{2}{*}{$\mathbf{p}$} & \multicolumn{2}{|c|}{ 95\% Confidence Interval } \\
\hline & & & & & Lower & Upper \\
\hline$I_{1} \_1$ & 0.018 & 0.013 & 1.356 & 0.175 & -0.008 & 0.043 \\
\hline IFA_2 & 0.599 & 0.051 & 11.693 & $<0.001$ & 0.498 & 0.699 \\
\hline IFA_3 & 0.270 & 0.024 & 11.302 & $<0.001$ & 0.224 & 0.317 \\
\hline IFA_4 & 0.119 & 0.011 & 11.235 & $<0.001$ & 0.098 & 0.139 \\
\hline IFA_5 & 0.370 & 0.037 & 10.100 & $<0.001$ & 0.298 & 0.442 \\
\hline II_1 & 0.251 & 0.021 & 11.716 & $<0.001$ & 0.209 & 0.292 \\
\hline II_2 & 0.246 & 0.022 & 11.125 & $<0.001$ & 0.203 & 0.290 \\
\hline II_3 & 0.459 & 0.045 & 10.287 & $<0.001$ & 0.372 & 0.546 \\
\hline II_4 & 1.123 & 0.096 & 11.729 & $<0.001$ & 0.935 & 1.311 \\
\hline II_5 & 0.189 & 0.018 & 10.784 & $<0.001$ & 0.154 & 0.223 \\
\hline IMP_1 & 0.128 & 0.011 & 11.149 & $<0.001$ & 0.106 & 0.151 \\
\hline IMP_2 & 0.167 & 0.015 & 11.477 & $<0.001$ & 0.138 & 0.195 \\
\hline IMP_3 & 0.677 & 0.057 & 11.797 & $<0.001$ & 0.565 & 0.790 \\
\hline IMP_4 & 0.617 & 0.052 & 11.828 & $<0.001$ & 0.515 & 0.720 \\
\hline IMP_5 & 0.001 & 0.014 & 0.102 & $0.919^{*}$ & -0.026 & 0.029 \\
\hline OEs & 0.142 & 0.012 & 11.832 & $<0.001$ & 0.118 & 0.165 \\
\hline
\end{tabular}

Note: * not included in the model formation because not significant at 0.05 level of significance.

Table 4. Intercepts.

\begin{tabular}{l|c|c|c|c|c|c}
\hline \multicolumn{9}{l}{ Estimate } & Std. Error & z-value & p & 95\% Confidence Interval \\
\hline Indicator & Lower & Upper \\
\hline IFA_1 & 3.179 & 0.039 & 80.885 & $<0.001$ & 3.102 & 3.256 \\
\hline IFA_2 & 2.036 & 0.052 & 39.367 & $<0.001$ & 1.934 & 2.137 \\
\hline IFA_3 & 3.664 & 0.040 & 90.530 & $<0.001$ & 3.585 & 3.744 \\
\hline IFA_4 & 3.236 & 0.027 & 118.512 & $<0.001$ & 3.182 & 3.289 \\
\hline IFA_5 & 2.625 & 0.058 & 45.097 & $<0.001$ & 2.511 & 2.739 \\
\hline II_1 & 3.746 & 0.031 & 121.131 & $<0.001$ & 3.686 & 3.807 \\
\hline II_2 & 3.754 & 0.034 & 110.788 & $<0.001$ & 3.687 & 3.820 \\
\hline II_3 & 3.157 & 0.050 & 62.969 & $<0.001$ & 3.059 & 3.255 \\
\hline II_4 & 2.939 & 0.065 & 45.035 & $<0.001$ & 2.811 & 3.067 \\
\hline II_5 & 3.721 & 0.031 & 120.908 & $<0.001$ & 3.661 & 3.782 \\
\hline IMP_1 & 3.700 & 0.027 & 135.105 & $<0.001$ & 3.646 & 3.754 \\
\hline IMP_2 & 3.593 & 0.029 & 122.369 & $<0.001$ & 3.535 & 3.650 \\
\hline IMP_3 & 3.104 & 0.052 & 59.404 & $<0.001$ & 3.001 & 3.206 \\
\hline IMP_4 & 3.071 & 0.048 & 64.357 & $<0.001$ & 2.978 & 3.165 \\
\hline IMP_5 & 3.486 & 0.033 & 106.527 & $<0.001$ & 3.422 & 3.550 \\
\hline OEs & 3.829 & 0.023 & 169.985 & $<0.001$ & 3.784 & 3.873 \\
\hline
\end{tabular}

